\title{
BLV-CoCoMo-qPCR: estimation of bovine leukemia virus (BLV) proviral load harbored by lymphocyte subpopulations in BLV-infected cattle at the subclinical stage of enzootic bovine leucosis
}

Yoko Aida ${ }^{*}$, Shin-nosuke Takeshima ${ }^{1}$, Carlos Javier Panei ${ }^{1,2}$, Takashi Omori ${ }^{3}$, Tetsuo Nunoya ${ }^{3}$, William C Davis ${ }^{4}$, Hiroshi Ishizaki ${ }^{5}$, Kazuhiro Matoba ${ }^{5}$

From 16th International Conference on Human Retroviruses: HTLV and Related Viruses Montreal, Canada. 26-30 June 2013

Bovine leukemia virus (BLV) is associated with enzootic bovine leukosis (EBL), which is the most common neoplastic disease of cattle. The present study reports the distribution of BLV provirus in peripheral blood mononuclear cell subpopulations isolated from BLV-infected cows at the subclinical stage of EBL as examined by cell sorting and a new quantitative real-time PCR method, BLV-CoCoMo-qPCR, to measure the proviral load of both known and novel BLV variants in BLV-infected animals. Phenotypic characterization of five BLV-infected but clinically normal cattle with a proviral load of $>100$ copies per $1 \times 10^{5}$ cells identified a high percentage of $\mathrm{CD}^{+} \mathrm{IgM}^{+}$cells (but not $\mathrm{CD}^{-} \mathrm{IgM}^{+}$B cells, CD4 ${ }^{+}$ $\mathrm{T}$ cells, or $\mathrm{CD} 8^{+} \mathrm{T}$ cells). These lymphocyte subpopulations were purified from three cattle by cell sorting or using magnetic beads, and the BLV proviral load was estimated using BLV-CoCoMo-qPCR. The $\mathrm{CD}^{+} \mathrm{IgM}^{+}$ $B$ cell population in all animals harbored a higher BLV proviral load than the other cell populations. The copy number of proviruses infecting $\mathrm{CD}^{-} \mathrm{IgM}^{+} \mathrm{B}$ cells, $\mathrm{CD} 4^{+}$ cells, and $\mathrm{CD}^{+} \mathrm{T}$ cells (per $1 \mathrm{ml}$ of blood) was $1 / 34$ to $1 / 4$, $1 / 22$ to $1 / 3$, and $1 / 31$ to $1 / 3$, respectively, compared with that in $\mathrm{CD}^{+} \mathrm{IgM}^{+} \mathrm{B}$ cells. Moreover, the BLV provirus remained integrated into the genomic DNA of $\mathrm{CD}^{+} \mathrm{IgM}^{+}$ $\mathrm{B}$ cells, CD5 $\mathrm{IgM}^{+} \mathrm{B}$ cells, $\mathrm{CD} 4^{+} \mathrm{T}$ cells, and $\mathrm{CD} 8^{+} \mathrm{T}$ cells, even in BLV-infected cattle with a proviral load of $<100$ copies per $10^{5}$ cells.

* Correspondence: aida@riken.jp

'Viral Infectious Diseases Unit, RIKEN, 2-1 Hirosawa, Wako, Saitama, Japan

Full list of author information is available at the end of the article

\section{Authors' details}

'Viral Infectious Diseases Unit, RIKEN, 2-1 Hirosawa, Wako, Saitama, Japan. ${ }^{2}$ CONICET and Virology Laboratory, Faculty of Veterinary Sciences, National University of La Plata, Argentina. ${ }^{3}$ Nippon Institute for Biological Science, Tokyo, Japan. ${ }^{4}$ Department of Veterinary Microbiology and Pathology, Washington State University, Pullman, WA, USA. ${ }^{5}$ NARO Institute of Livestock and Grassland Sciences, Tochigi, Japan.

Published: 7 January 2014

\section{doi:10.1186/1742-4690-11-S1-P143}

Cite this article as: Aida et al: BLV-CoCoMo-qPCR: estimation of bovine leukemia virus (BLV) proviral load harbored by lymphocyte

subpopulations in BLV-infected cattle at the subclinical stage of enzootic bovine leucosis. Retrovirology 2014 11(Suppl 1):P143.
Submit your next manuscript to BioMed Central and take full advantage of:

- Convenient online submission

- Thorough peer review

- No space constraints or color figure charges

- Immediate publication on acceptance

- Inclusion in PubMed, CAS, Scopus and Google Scholar

- Research which is freely available for redistribution
() Biomed Central 